\title{
Spatial Variability of Soil pH, EC and Organic Carbon in Different Panchayats of Sabour Block of Bhagalpur District, Bihar, India
}

\author{
Neeraj Bagoria ${ }^{1 *}$, Binod Kumar Vimal ${ }^{1 *}$, Y. K. Singh ${ }^{1}$, Rakesh Kumar ${ }^{1}$, Ragini Kumari ${ }^{1}$, \\ Raj Kishore kumar ${ }^{1}$, Birendra Kumar ${ }^{2}$, Satish Kumar ${ }^{3}$ and Rajendra Bairwa ${ }^{4}$ \\ ${ }^{1}$ Department of Soil Science and Agricultural Chemistry, ${ }^{2}$ Department of Agronomy Bihar \\ Agricultural University, India \\ ${ }^{3}$ Department of Agricultural Engineering, Bihar Agricultural University, \\ Sabour, Bhagalpur-813210, India \\ ${ }^{4}$ Department of Soil Science and Agricultural Chemistry, Dr. Rajendra Prasad Central \\ Agricultural University, Samastipur, Bihar, India \\ *Corresponding author
}

\section{A B S T R A C T}

\section{Keywords}

Soil $\mathrm{pH}$, Organic carbon, GPS

receiver,

Interpolation, Soil

fertility and Spatial

variability

\section{Article Info}

Accepted:

07 August 2020

Available Online:

10 September 2020
Soil pH, EC and Organic Carbon are the essential parameters used as the primary level health status of the soils. In this context, detailed study over soil $\mathrm{pH}, \mathrm{EC}$ and $\mathrm{OC}$ was done for different panchayats of Sabour block of Bhagalpur district. 80 composite surface soil samples $(0-15 \mathrm{~cm})$ using GPS receiver from different location of fourteen Panchayats of Sabour block were collected during the months of May and June, 2019. The sample points were recorded in GPS receiver to find out the coordinate(s) and used to record the data of soil parameters viz. $\mathrm{pH}, \mathrm{EC}$ and organic carbon in excel file towards the analysis of spatial variability and correlation using interpolation (IDW) technique. It was observed that soil $\mathrm{pH}$ under $52.5 \%$ soil samples was as neutral and $41.25 \%$ soil samples were slightly alkaline in nature. However, the range of EC was under in non-saline category and varies from 0.10 to $0.36 \mathrm{dSm}^{-1}$. While organic carbon ranged from $0.15-0.49 \%$ with a mean value of $0.33 \%$ which was positively correlated with soil $\mathrm{pH}$ and EC. Normal EC indicated the safe for all agricultural crops. However, organic carbon was low in all the panchayats which is needed to be management practices.

\section{Introduction}

Soil is considered as a natural resource where all agricultural activities are being done towards promotion of agricultural economics. (Sehgal, 1996) reported that systematic study of soils provided an opportunity to understand the soil health to accelerate the land use planning in area of interest. In this context, soil $\mathrm{pH}, \mathrm{EC}$ and $\mathrm{OC}$ are important parameters that affect plant growth. Amacher et al., (2007) reported that $\mathrm{pH}$ is used as an indicator of the acidity or alkalinity presence in soils which controls the mobility and the availability of soil nutrients. If a soil is too sour or too sweet, plants cannot take up 
nutrients like nitrogen $(\mathrm{N})$, phosphorus $(\mathrm{P})$ and potassium (K) (Buckman et al., 2002). Some nutrients such as nitrogen, phosphorus, and potassium are less available when $\mathrm{pH}$ is $<6.0$ (acidic condition). In same manner, if $\mathrm{pH}$ is very alkaline, Iron, manganese and phosphorus are less available. (Wang et al., 2006) reported that low $\mathrm{pH}$ causes deficiency and unavailability of plant nutrients like $\mathrm{P}$, $\mathrm{Ca}, \mathrm{K}, \mathrm{Mg}$ and Mo. (Vimal et al., 2016) reported that red soils were found in hilly terrain of Banka district of Bihar which is acidic in nature having low nitrogen. Vinay et al., (2013) reported that light textured soils visually interpreted as white by using visual interpretation keys of satellite image of Diara land of Bhagalpur district, Bihar. (Khadka et al., 2018) digitized the Chungbang farm, Pakhribas, Dhankuta, Nepal to identify the actual land for soil fertility mapping. The organic carbon was mapped for Agricultural Research Station, Bijayanagar, Jumla, Nepal by (Khadka et al., 2011).

To identify the actual land which is used for agriculture only under different Panchayats of Sabour block, Bhagalpur and the status of soil $\mathrm{pH}, \mathrm{EC}$ and $\mathrm{Ca}$ in that cultivated land are current lacking. To fill these gaps, an attempt was taken to map the soil $\mathrm{pH}, \mathrm{EC}$ and $\mathrm{Ca}$ towards their spatial variability in different Panchayats of Sabour block of Bhagalpur district.

\section{Materials and Methods}

\section{Study area}

Sabour block of Bhagalpur district, Bihar was selected to study the soil $\mathrm{pH}, \mathrm{EC}$ and OC. It is situated adjoining of river Ganges having geographical extension of 24030' to 2506'N and 86030'E to 87007'E. The eastern and southern border of the block coincide with Goradih and Sanhaula blocks. In west and south it touches with Nathnagar and
Jagdishpur blocks respectively (Fig. 1). The geographical area of the study area is 115.51 having fourteen panchayats. Field survey was done during the month of June, 2019 and 80 soil samples were collected from different location with GPS reading to analyse the soil parameters of soil $\mathrm{pH}, \mathrm{EC}$ and $\mathrm{Ca}$ using the standard procedure.

\section{Hardware, software and satellite data}

Computer system (HP Pentium due core 5i processor), QGIS software, satellite image of Landsat 8 of May, 2019 and GPS receiver were used for Digital Image Processing (DIP) and mapping. Toposheets and ancillary data were also used for ground truthing and validation of derived data.

\section{Soil analysis procedure}

Collected soil samples from different location were air dried in shade, crushed and sieved from $<2 \mathrm{~mm}$ sieve for the analysis of soil $\mathrm{pH}$, EC and Organic carbon in the laboratory. Tested procedures and methods were used for the assigned parameters were tabulated (Table 1).

\section{Statistical analysis and soil fertility mapping}

Latitude, longitude and laboratory analysed data/results were inserted in attribute table (MS-Excel) and converted into csv file. Format to open in QGIS software towards generation of thematic maps of soil $\mathrm{pH}, \mathrm{EC}$ and organic carbon. Interpolation technique (IDW) was used to map the spatial variability. (Hengl, 2009) used Inverse Distance Methods (IDW) of interpolation to find out the soil fertility status and to separate it from an ordinary map because geo-statistical map is a predicted map which was created based on quantitative statistical methods. 


\section{Methodology for digital mapping}

Satellite data (Landsat 8) was used for visual interpretation of the different land use pattern of the study area and selection of the different locations of the soil samples. However, topographical sheets ( $\mathrm{P} 45$ and O45) were used to trace out the block and village boundaries on a plain sheet and traced boundaries were geo-referenced to digitize the boundaries in shape files (shap File). Digitized files were used to subset the land sat 8 data for visual interpretation, mapping and selection of the locations of the soil samples. Based on analysed soil samples, interpolation technique was used to map the spatial variability of soil $\mathrm{pH}, \mathrm{EC}$ and organic carbon and results were ground truth by using toposheets, GPS receiver and documented reports were used for the validation of data.

\section{Results and Discussion}

\section{Soil pH}

Based on visual interpretation layer stacked bands of green, red and NIR bands of satellite (Landsat-8) image, whitish tone having high brightness values was observed in adjoining of river Ganges, where soil reaction was under 7.00 to 7.9 In southern part, tone of the soils was appeared as bluish in same bands, where the range of soil $\mathrm{pH}(6.19-7.95)$ was slightly alkaline (Fig. 3a). In general, soils with near neutral reaction $(\mathrm{pH}$ 6.0-7.0) are the most fertile (LRMP, 1986). The $\mathrm{pH}$ of the soils of Sabour Block describe that only $6.25 \%$ soils were moderately acidic due to high rainfall in some part of Sabour Block. $41.25 \%$ soil samples were slightly alkaline in reaction might be due to medium black soils and $52.50 \%$ soils were Neutral soils. Soil had $\mathrm{pH}$ less than 8.0 might be due to soil were well drained and light in colour. Similar results reported by Chitdeshwari et al.,2017 in Cuddalore District of Tamil Nadu and conclude that soil reaction ranged from acidic to slightly alkaline which is might be due to high base saturated in respective area (Fig. 2).

\section{Soil EC}

The Electric Conductivity of the analyzed soil samples was ranged from 0.10-0.36 dSm-1 with an average mean of $0.20 \mathrm{dSm}-1$ indicated all the 80 soil samples $(100 \%)$ were non saline nature. The result indicated that all the soils are normal in nature (Fig. 4a). Similar results were reviewed by Golhar and Chaudhari (2013) at Chalisgaon Tehsil of Jalgaon District, Maharashtra. The wide variation of EC has also been observed with low salt content because of inherent drainage capacity prevailed over respective panchayat at sabour block. As a result, there was barely evidence of salinity hazards in potential zone. Similar results were also reported by Salma et al., (2019), who stated that low EC unable to favored the accumulation of salts at succeeding depth.

\section{Organic Carbon}

The organic carbon content ranged from 0.15 $0.49 \%$ with the mean of $0.33 \%$ and categories under low fertility status (Map 5, (a). It might be attributed low organic carbon content prevailed across the sabour block. Despite of low application of FYM and crop residues, rapid rate of decomposition with no scientific management practices followed by farmers pose to fast degradation of organic matter because of high temperature, as on that removal takes place at faster rate coupled with low vegetation cover. Thereby, leaving less changes of accumulation of organic matter in surface layer, which enable to further exacerbate the situation in respective panchayat at sabour block. Similar findings were corroborated with Singh et al., (2018) in soils of Uttar Pradesh and Jagtap (2007) in soil of Chakur and Shirpuranantpal Tehsil, Maharashtra (Fig. 5). 
Table.1 Method of Analysis for Chosen Soil properties

\begin{tabular}{|l|l|l|l|}
\hline S. No. & \multicolumn{1}{|c|}{ Parameter } & \multicolumn{1}{|c|}{ Method } & \multicolumn{1}{c|}{ Reference } \\
\hline 1 & $\mathrm{pH}$ & Soil-Water Suspension & Jackson, 1973 \\
\hline 2 & EC $(\mathrm{dSm}-1)$ & Soil-Water Suspension & Jackson, 1973 \\
\hline 3 & Organic Carbon $(\%)$ & Wet oxidization method & Walkley and Black, 1934 \\
\hline
\end{tabular}

Fig.1 Location map of the study area

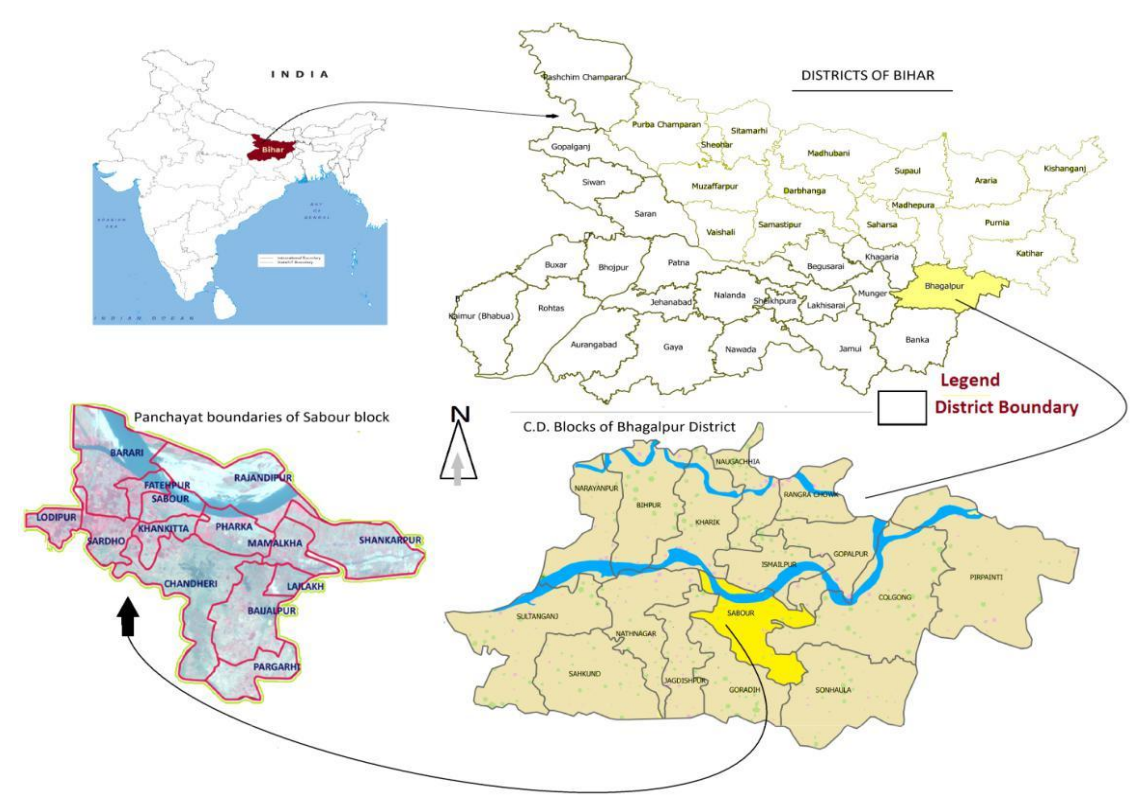

Fig.2 Flow Soil chart pH of the methodology

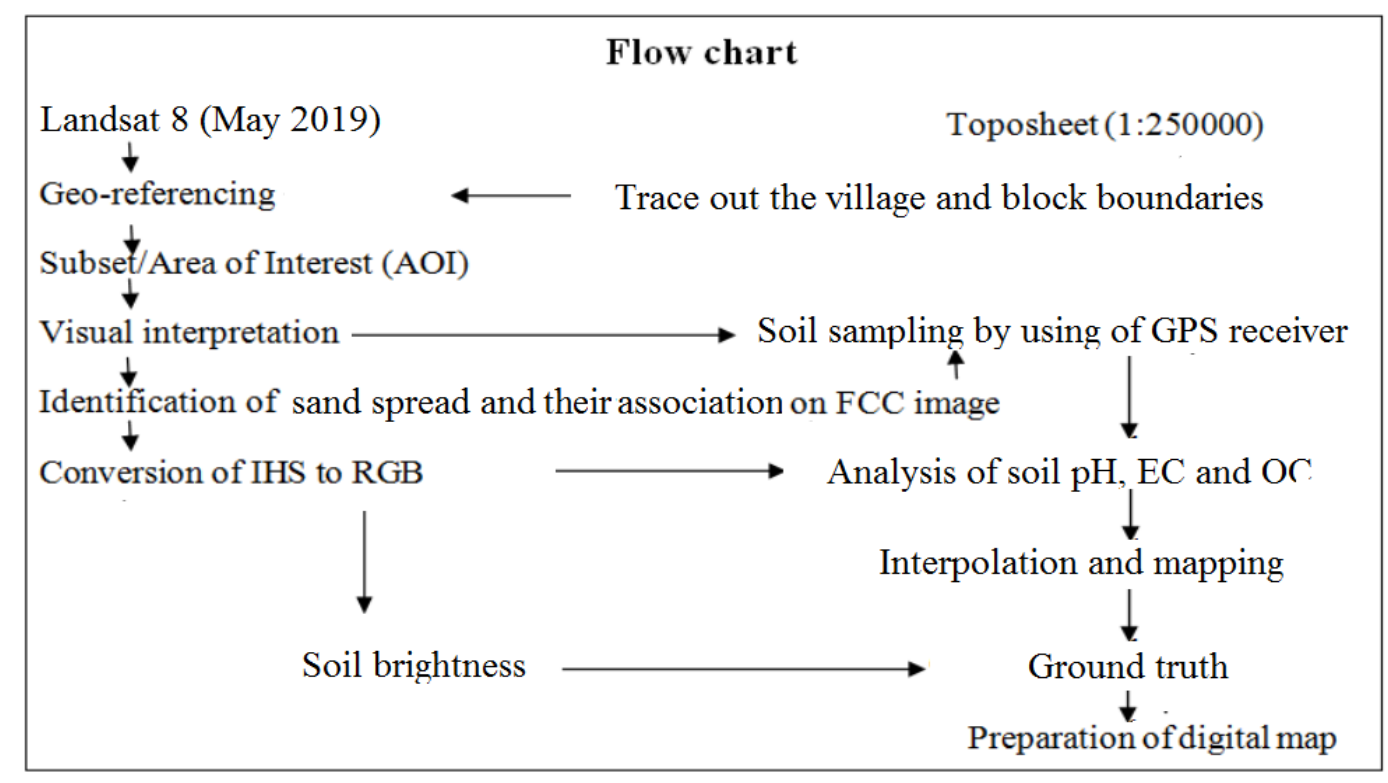


Fig.3 (a) Map showing spatial variability of soil $\mathrm{pH}$

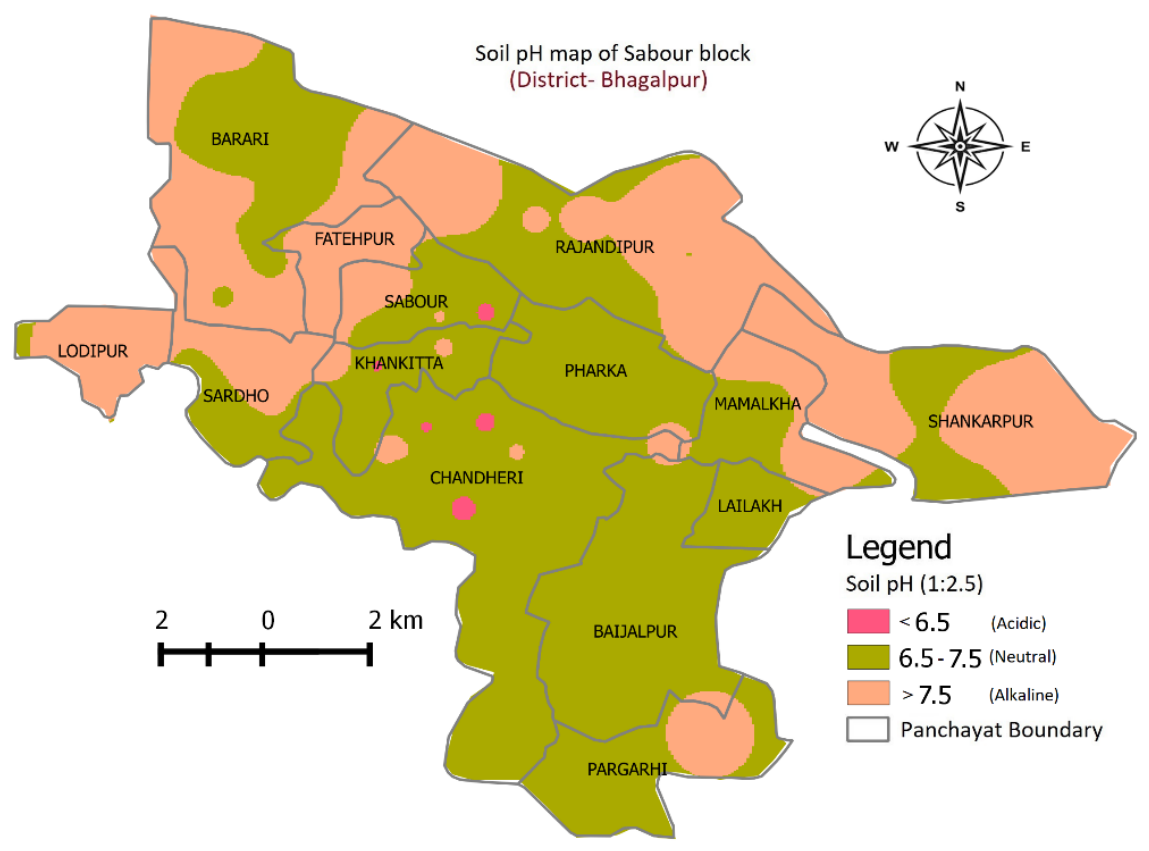

Fig.3 (b) Pie diagram showing status of soil pH

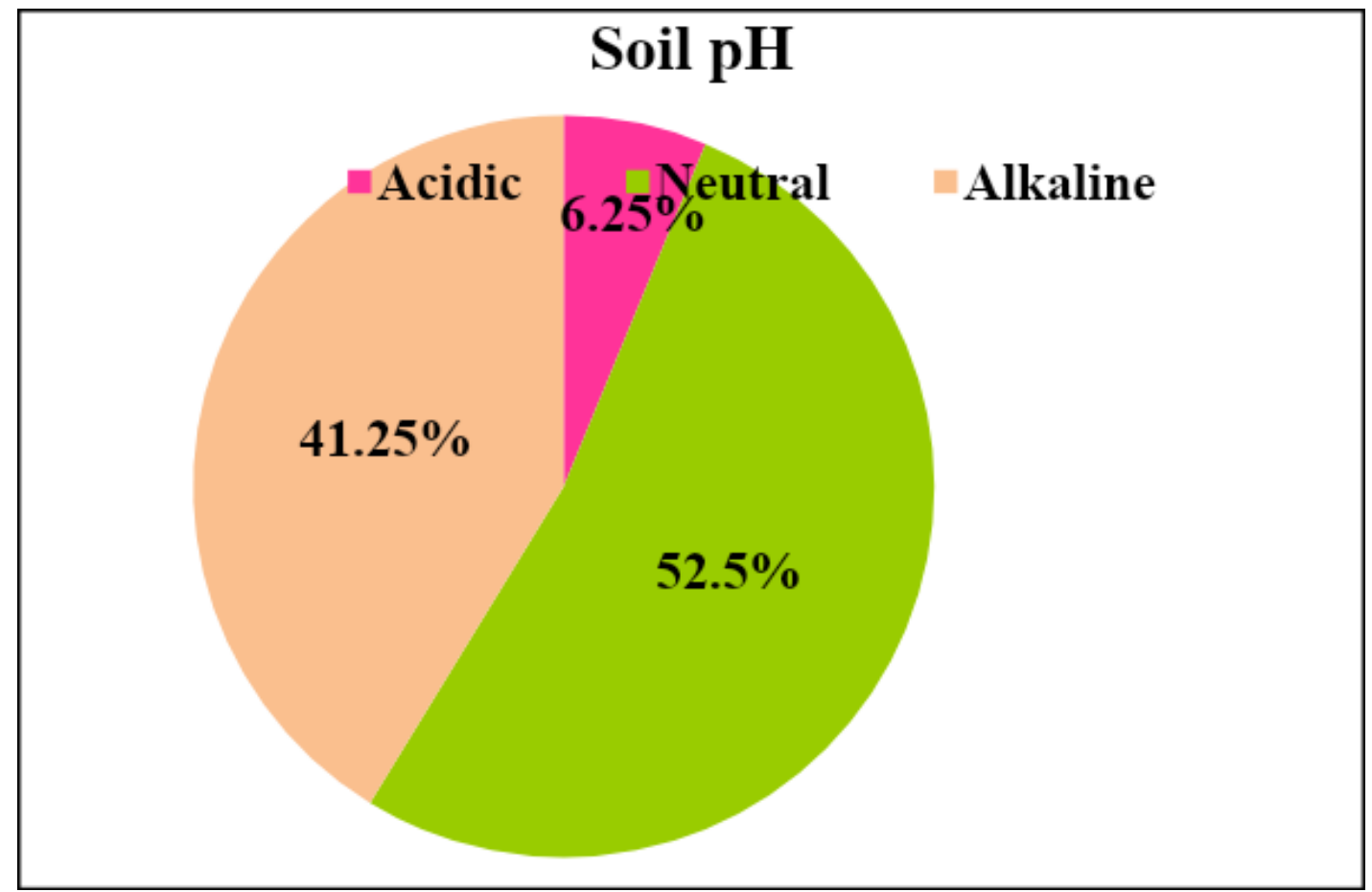


Fig.4 (a) Map showing spatial variability of soil EC

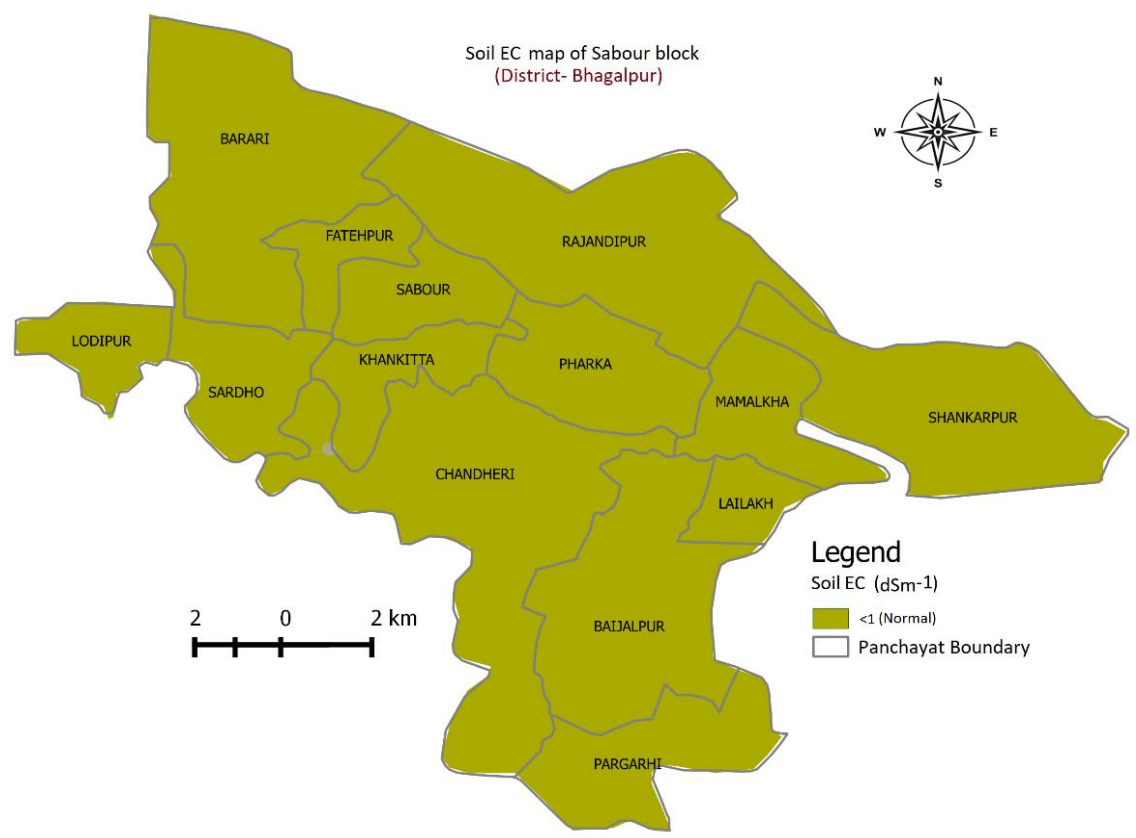

Fig.4 (b) Pie diagram showing status of soil EC

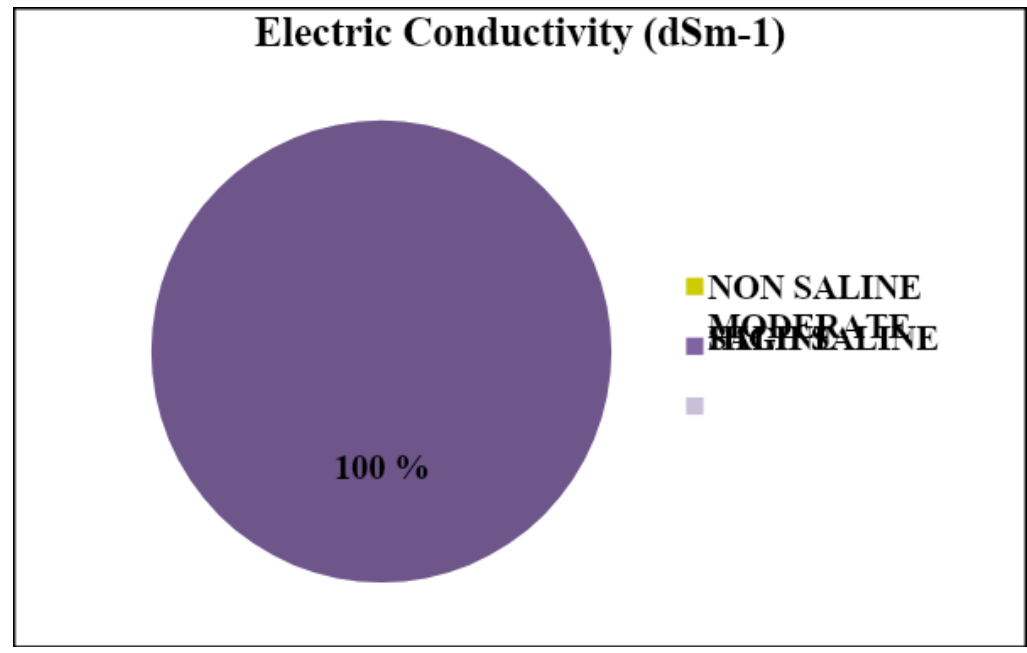

Table.2 Statistical Analysis of Nutrient

\begin{tabular}{|l|c|c|c|c|c|c|c|}
\hline Sr. No. & $\begin{array}{c}\text { Soil } \\
\text { Parameters }\end{array}$ & $\begin{array}{c}\text { Total number } \\
\text { of the soil } \\
\text { Samples }\end{array}$ & Mean & Range & CV & $\begin{array}{c}\text { Standard } \\
\text { Deviation }\end{array}$ & $\begin{array}{c}\text { Standard } \\
\text { Error }\end{array}$ \\
\hline 1 & $\begin{array}{c}\text { Soil pH } \\
(1: 2.5)\end{array}$ & 80 & $\mathbf{7 . 3 8}$ & $\begin{array}{c}\mathbf{6 . 1 9}- \\
\mathbf{7 . 9 5}\end{array}$ & $\mathbf{5 . 9 5}$ & $\mathbf{0 . 4 4}$ & $\mathbf{0 . 0 5}$ \\
\hline 2 & $\begin{array}{c}\text { EC (1:2.5) } \\
\text { (dSm-1) }\end{array}$ & 80 & $\mathbf{0 . 2 0}$ & $\mathbf{0 . 1 0 - 0 . 3 6}$ & $\mathbf{2 9 . 5 2}$ & $\mathbf{0 . 0 6}$ & $\mathbf{0 . 0 1}$ \\
\hline 3. & OC (\%) & 80 & $\mathbf{0 . 3 3}$ & $\mathbf{0 . 1 5}-\mathbf{0 . 4 9}$ & $\mathbf{2 4 . 9 9}$ & $\mathbf{0 . 0 8}$ & $\mathbf{0 . 0 1}$ \\
\hline
\end{tabular}


Fig.5 (a) Map showing spatial variability of soil OC

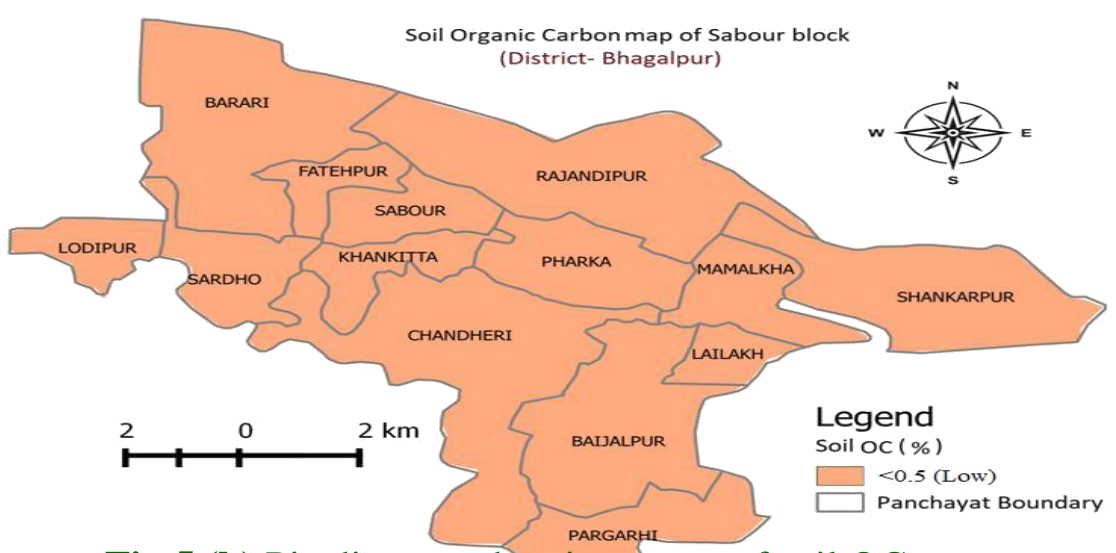

Fig.5 (b) Pie diagram showing status of soil OC

\section{Spatial distribution}

Results of the tested soil samples and their maps indicated that most of the land is normal in context of Soil EC. Soil pH value was observed within the neutral to slightly alkaline and EC was saline free. In context of spatial variation of soil pH, Chandheri, Baijalpur, Mamalkha and Farka panchayats have neutral range indicated the maximum coverage of cropping sequences. However, result of EC and OC indicated that all the panchayats have non saline in nature (Table 2).

In conclusion, results of the tested soil samples and their maps indicated that most of the land is normal in context of Soil EC. Soil pH value was observed within the neutral to slightly alkaline and EC was non saline. Organic carbon content is low in sabour block due to tropical climatic conditions which cause rapid decomposition of organic matter. In context of spatial variation of soil pH, Chandheri, Baijalpur, Mamalkha and Farka panchayats have neutral range indicated the maximum coverage of cropping sequences. However, result of EC and OC indicated that all the panchayats have non saline and low organic matter status. Results were demonstrated in digital maps helpful for initial information towards promotion of land use planning at Panchayats level.

\section{Acknowledgement}

Chairman, Department of Soil Science and Agricultural Chemistry, BAC, Sabour is acknowledged for his cooperation's and providing laboratory facility with BAU COMMUNICATION NO. 830/2020. Mr. B. K. Vimal is also thankfully acknowledged for his valuable suggestions and guidance throughout the PG research work. 


\section{References}

Ama, Thierry \& Rufus J. RogerScher, ott LDA. Chaney Mngle. R Delorme. eves., Nil, O., Katherine, P. and Charles, H. 2007. Soil vital signs: A new Soil Quality Index (SQI) for assessing forest soil health. Res. Pap. RMRSRP-65WWW. Fort Collins, CO: U.S. Department of Agriculture, Forest Service, Rocky Mountain Research Station. 12 pp.

Buckman, H. O., Brady, N. C., and Weil, R. R. 2002. The nature and properties of soils, 13th Edition. Prentice Hall.

Chitdeshwari, T., Santhi, R., Radhika, K., Sivagnanam, S., Hemalatha, S., Dey, P. and Subba Rao, A. 2017. GPS and GIS Based Soil Fertility Mapping for Cuddalore District of Tamil Nadu. Madras Agriculture Journal. $104 \quad$ (7-9): 251-257; doi: 10.29321/MAJ.2017.000054.

Cressie, N. 1992. Statistics for Spatial Data, (Wiley: New York). 261 pp.

Golhar, NP. and Chaudhari, P. R. 2013. Level of significance of various physical and chemical parameters of soils through Electrical Conductivity, Journal of Chemical, Biological and Physical Science. 3(3): 20512057.

Hengel, T. 2009. A Practical Guide to Geostatistical Mappin. Chapter-Geospatial Mapping. PP24-26, ISBN-978-90-9024981-0.

Jackson, M. L. 1967. Soil Chemical Analysis (Edn. 2) Prentice Hall of Indian PVT. Ltd. New Delhi. Pp. 82-190.

Jagtap, V. R. 2007. Physico-chemical characteristics and status of NPK and some micronutrients in soils from Chakur and Shirur-anantpal tahsils of latur district. M.Sc. (Agri) Thesis submitted to Marathwada Agriculture University, Parbhani.(M.S) India.

Joseph, G. 2003. Fundamentals of remote sensing, University Press, Hyderabad. pp-65-66. Khadka, D., Lamichhane, S., Amgain, R., Joshi, S., Shree, P., Sah, K. and Netra, H.
2011. Soil fertility assessment and mapping spatial distribution of Agricultural Research Station, Bijayanagar, Jumla, Nepal, Eurasian Journal of Soil Science. 8(3) 237-248.

Khadka, D., Lamichhane, S., Bhantana, P., Ansari, A. R., Joshi, S. and Baruwal, P. 2018. Soil fertility assessment and mapping of chungbang farm, Pakhribas, Dhankuta, Nepal, Advances in Plants \& Agriculture Research. 8(3).

LRMP, 1986. Land capability report and maps. Kathmandu: Land Resources Mapping Project/ HMG and Ottawa, Canada: Kenting Earth Science.

Panda, B. C. 2009. Remote sensing: Principle and application. Viva Books Pvt Ltd.

Salma, D., Munaswamy, V., Giridhara, K. T., Sumathi, V. and Reddy, B. R. 2019. GPS and GIS based Soil Fertility Maps and Identification of Soil Related Constraints for Chickpea Growing Soils of Owk Mandal, Kurnool District (A.P), India. International Journal of Current Microbiology and Applied Sciences, 8(6): 1241-1247.

Sehgal, J. L. 1996. Pedology - Concepts and Application, Kalyani Publishers, New Delhi. pp. 1-488.

Vimal, B. K., Kumar, S., Pradhan, A., K., Kumari, R., Parveen, H. and Gupta, S., K. 2019. Remote Sensing and GIS based Mapping of Clay Soils- A Case Study of Patna District, Bihar, India International Journal of Current Microbiology and Applied Sciences. 8 (4):2319-7706

Walkley, A. and Black, C. A. 1934. An Examination of Wet Acid Method for Determining Soil Organic Matter and a Proposed Modification of the Chromic Acid Titration Method. Soil Science. 37: 29-38.

Wang, A. S., Angle, J. S., Chaney, R. L., Delorme, T. A. and Reeves, R. D. 2006. Soil pH effects on uptake of $\mathrm{Cd}$ and $\mathrm{Zn}$ by Thlaspi caerulescens, Plant and Soil. 281:325-337, DOI 10.1007/s11104-005-4642-9.

\section{How to cite this article:}

Neeraj Bagoria, Binod Kumar Vimal, Y. K. Singh, Rakesh Kumar, Ragini Kumari, Raj Kishore kumar, Birendra Kumar, Satish Kumar and Rajendra Bairwa. 2020. Spatial Variability of Soil pH, EC and Organic Carbon in Different Panchayats of Sabour Block of Bhagalpur District, Bihar, India. Int.J.Curr.Microbiol.App.Sci. 9(09): 756-763. doi: https://doi.org/10.20546/ijcmas.2020.909.095 